
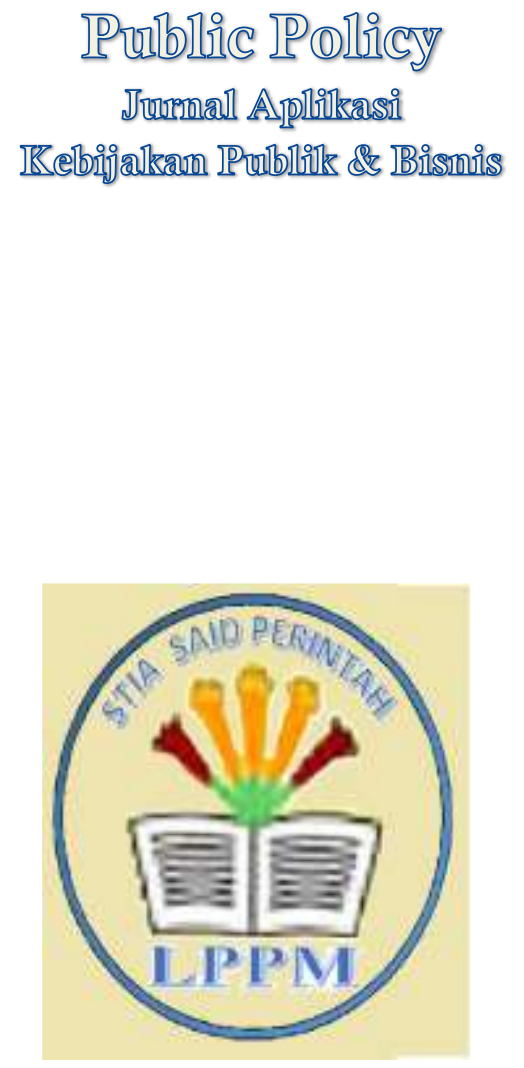

LPPM STIA Said Perintah

Volume 1, No. 2, September 2020

https://stia-saidperintah.e-journal.id/ppi

\section{Pengaruh Beban Kerja dan Lingkungan Kerja Terhadap Kinerja Pegawai}

\author{
Muhammad Nur Deni Musa \\ Fakultas Ekonomi Universitas Iqra Buru \\ mohnur.denymusa@gmail.com
}

Herman Surijadi

Administrasi Bisnis Politeknik Negeri Ambon

hermansurijadi@yahoo.co.id

(Penulis Korespondensi)

\begin{abstract}
The purpose of this study was to examine and analyze the effect of workload and work environment on employee performance. The population of this study were all employees of the Civil Registry Office of Buru Regency. The sampling technique used a census technique with a final sample size of 39 respondents. The research data collection was obtained through a questionnaire instrument while the research data analysis used multiple linear regression analysis. The results showed that the workload and work environment proved to have a positive and significant effect on the performance of the employees of the Buru Regency Civil Registry, where the influence of the work environment is greater than the effect of workload. Thus it can be said that an increase in the value of workload and work environment will improve the performance of employees of the Civil Registry Office of Buru Regency.

Keywords : Workload, Work Environment, Performance
\end{abstract}

\title{
Pendahuluan
}

Pemungutan suara Pilpres dan Pilkada tahun 2009, Indonesia dihebohkan dengan meninggalnya petugas Kelompok Penyelenggara Pemungutan Suara (KPPS) ketika melaksanakan tugasnya. Data Kementerian Kesehatan (Kemenkes) melalui dinas kesehatan tiap provinsi mencatat petugas KPPS yang sakit sudah mencapai 11.239 orang dan korban meninggal 527 jiwa (Pratama, Ilham, Pratama, \& Editor, 2019). Tim peneliti dari Universitas Gadjah Mada (UGM) mengungkapkan kesakitan dan kematian petugas KPPS (Kelompok Penyelenggara Pemungutan Suara) pada Pemilu 2019 disebabkan oleh beban kerja yang sangat tinggi. Bukti lainnya menyangkut beban kerja berlebihan juga disampaikan melalui sebuah studi pada Journal of Occupational and Environmental Medicine meyebutkan bahwa 
ada korelasi antara jam kerja dalam seminggu dengan risiko serangan jantung. Orang yang bekerja 55 jam seminggu, 16 \% lebih mungkin mengembangkan risiko serangan jantung dibanding mereka yang bekerja 45 jam seminggu seperti yang dilansir oleh Kesehatan.kontan.co.id, (2019). Studi itu menemukan bahwa orang yang bekerja 65 jam seminggu memiliki peluang mengalami serangan jantung sebesar 33\%. Studi empiris yang terbit 2014 di jurnal Psychosomatic Medicine mengungkapkan bahwa tingginya beban pekerjaan berkaitan dengan diabetes, peluang risikonya bisa mencapai 45 \%. Merasa terlalu banyak bekerja juga dapat merusak kesehatan mental (Kesehatan.kontan.co.id, 2019).

Fakta dan bukti empiris di atas membuktikan bahwa beban kerja yang berlebihan tidak bisa dianggap hal yang biasa karena dampaknya yang sangat menakutkan, bukan hanya berdampak pada kinerja karyawan atau pegawai tapi bahkan sampai pada tingkat kematian. Di Indonesia sendiri, kajian empiris yang menyoroti dampak beban kerja dan lingkungan kerja terhadap kinerja pegawai telah banyak disampaikan. Hasil penelitian Sutoyo, (2016); Fikratunil Khasifah, (2016); Zulkifli, (2016) dan Fernando Reinhard Tjiabrata, (2017) menyebutkan bahwa beban kerja berpengaruh signifikan terhadap kinerja pegawai. Namun demikian, penelitian Fikratunil Khasifah, (2016) dan Riny Chandra dan Dody Adriansyah, (2015), menyatakan bahwa beban kerja tidak berpengaruh signifikan terhadap kinerja pegawai. Bahkan hasil kajian Artha Tri Hastutiningsih, (2018) menemukan bahwa terdapat pengaruh yang negatif dan signifikan antara beban kerja terhadap kinerja.

Selain beban kerja yang berlebihan, kinerja pegawai/karyawan juga turut dipengaruhi oleh banyak faktor lain yang salah satunya adalah lingkungan kerja. Kondisi lingkungan kerja yang baik adalah salah satu faktor penunjang produktivitas karyawan yang pada akhirnya berdampak pada kenaikan tingkat kinerja karyawan. Kondisi ingkungan kerja dapat dibagi menjadi 2 (dua) yaitu lingkungan kerja fisik dan lingkungan kerja non-fisik (Sedarmayanti, 2009), contoh lingkungan kerja fisik adalah penerangan, warna dinding, sirkulasi udara, musik, kebersihan, dan keamanan. Lingkungan kerja non-fisik contohnya adalah struktur tugas, desain pekerjaan, pola kerja sama, pola kepemimpinan, dan budaya organisasi. Kondisi lingkungan kerja dikatakan baik apabila manusia dapat melaksanakan kegiatannya secara optimal, sehat, aman, dan nyaman Sutoyo, (2016); Fikratunil Khasifah, (2016); Zulkifli, (2016) dan Fernando Reinhard Tjiabrata, (2017). 
Penelitian menyangkut dampak lingkungan kerja terhadap kinerja pegawai telah dilakukan oleh beberapa peneliti. Sutoyo, (2016), Fikratunil Khasifah, (2016), Zulkifli, (2016) dan Fernando Reinhard Tjiabrata, (2017) menyatakan bahwa lingkungan kerja berpengaruh positif signifikan terhadap kinerja pegawai. Namun demikian, ada juga penelitian yang menyatakan sebaliknya, seperti penelitian oleh Artha Tri Hastutiningsih, (2018); Soegoto, (2018) yang menyatakan bahwa terdapat pengaruh positif namun tidak signifikan antara lingkungan kerja terhadap kinerja karyawan. Bahkan Bahkan Aslian, (2019) berhasil mambuktikan bahwa lingkungan kerja tidak memiliki pengaruh terhadap kinerja karyawan.

Pemaparan hasil-hasil kajian empiris di atas menunjukan bahwa ada perbedaan hasil penelitian menyangkut dampak atau pengaruh beban kerja dan lingkungan kerja terhadap kinerja pegawai. Perbedaan hasil penelitian dapat memunculkan celah penelitian, sehingga oleh peneliti lain dapat dilakukan penelitian kembali (Agusty, 2006). Hal inilah yang memotivasi peneliti untuk meneliti tentang dampak beban kerja dan lingkungan kerja terhadap kinerja pegawai dengan unit analisis penelitian yang berbeda yakni pada Dinas Catatan Sipil Kabupaten Buru.

Alasan pemilihan Dinas Catatan Sipil Kabupaten Buru sebagai unit analisis penelitian karena terlihat bahwa dinas ini termasuk salah satu dinas yang paling banyak dikunjungi oleh masyarakat, apalagi pada momen-momen tertentu seperti pendaftaran tes CPNS. Gambaran kesibukan pada Dinas Catatan Sipil Kabupaten Buru ini, mengindikasikan bahwa potensi beban kerja lebih (work overload) sangat mungkin terjadi dan jika tidak ditunjang oleh lingkungan kerja yang baik maka dapat berdampak pada penurunan kinerja pegawai pada dinas tersebut. Hal tersebut ditunjang oleh penelitian Suraedah, Akib, dan Darwis (2015) yang menyatakan salah satu dinas yang memiliki beban kerja lebih adalah Dinas Catatan Sipil. Berdasarkan pemaparan fakta dan hasil kajian empiris di atas maka peneliti akan mengkaji lebih dalam lagi tentang dampak beban kerja dan lingkungan kerja terhadap kinerja pegawai Dinas Catatan Sipil Kabupaten Buru. Hasil penelitian ini diharapkan memberikan kontribusi bagi Dinas Catatan Sipil Kabupaten Buru agar dapat meningkatkan kinerja pegawai dengan memperhatikan beban kerja dan lingkungan kerja. 


\section{Kajian Pustaka}

\section{Beban Kerja}

Definisi beban kerja menurut Komaruddin Sastradipoera, (1996) bahwa analisa beban kerja adalah proses untuk menetapkan jumlah jam kerja orang yang digunakan atau dibutuhkan untuk merampungkan suatu pekerjaan dalam waktu tertentu. Moekijat, (1999) menambahkan bahwa analisis beban kerja yaitu penentuan jumlah pegawai yang diperlukan untuk menyelesaikan pekerjaan selama jangka waktu tertentu. Selanjutnya, pengukuran beban kerja dilakukan dengan mengadopsi pendapat Eduard Yohannis Tamaela, (2011); Tamaela, Hetharie, \& Huwae, (2018) dan Eduard Yohannis Tamaela \& Surijadi Herman, (2018) bahwa beban kerja dapat dikelompokkan dalam dua bagian yaitu beban kerja kuantitatif dan kualitatif.

\section{Lingkungan Kerja}

Salah satu faktor yang dapat mempengaruhi produktifitas karyawan adalah lingkungan kerja. Meskipun faktor tersebut sangatlah penting dan besar pengaruhnya, tetapi masih banyak perusahaan-perusahaan yang kurang memperhatikan hal tersebut. Sedarmayanti, (2009) mangatakan bahwa lingkungan fisik dalam arti semua keadaan yang terdapat di sekitar tempat kerja, akan mempengaruhi pegawai baik secara langsung maupun tidak langsung. Selajutnya lingkungan kerja dapat dikelompokan menjadi lingkungan kerja fisik dan non fisik (Surijadi \& Idris, 2020). Mereka menyatakan bahwa lingkungan non fisik adalah semua keadaan yang terjadi yang berkaitan dengan hubungan sesama rekan kerja, ataupun hubungan dengan bawahan. Lingkungan kerja yang tidak menyenangkan juga bisa disebabkan karena suasana kerja yang tidak kondusif, seperti adanya persaingan, teman sekerja saling menjatuhkan, dan adanya kerja sama yang jelek. Suasana kerja yang tidak mendukung seperti itulah yang membuat karyawan tidak kerasan kerja (Surijadi \& Idris, 2020).

\section{Kinerja}

Bernardin, H. J., \& Russel A. E. J., (1988) menyatakan bahwa kinerja adalah catatan mengenai akibat-akibat yang dihasilkan pada sebuah fungsi kerja atau kegiatan tertentu dalam suatu jangka waktu tertentu. Kinerja seorang individu merupakan gabungan dari kemampuan, usaha dan kesempatan yang dapat diukur dari akibat yang dihasilkan, oleh karena itu kinerja bukan menyangkut karakteristik pribadi yang ditunjukkan oleh seseorang 
melainkan hasil kerja yang telah dan akan dilakukan oleh seseorang. Pendapat lain oleh Motowidlo dan Van Scotter, (1994) dalam Agripa Fernando Tarigan, (2011) kinerja mengacu pada hasil- hasil yang diperoleh dari tugas-tugas yang substantif yang membedakan pekerjaan seseorang dengan pekerjaan yang lainnya serta meliputi aspek-aspek yang lebih teknis mengenai hasil kerja. Selanjutnya pengukuran variabel ini dilakukan dengan mengadopsi pendapat David Chan \& Neal Schmitt, (2002) yang mengoperasionalkan kinerja dalam 3 (tiga) dimensi utama yakni;

1) Keahlian Teknikal Inti / Kinerja Tugas (Core Technical Proficiency / Task Performance).

2) Dedikasi Kerja / Motivasional Kinerja Kontekstual (Job Dedication / Motivational Contextual Performance).

3) Fasilitas Interpersonal (Interpersonal Facilitation / Interpersonal Contextual Performance).

\section{Penelitian Terdahulu dan Pengembangan Hipotesa}

Kerangka konseptual kajian ini didasarkan pada tinjauan kepustakaan dan hasil penelitian terdahulu yang selanjutnya digunakan untuk kepentingan pengembangan hipotesa penelitian. Beberapa hasil kajian terdahulu yang mendasari pengembangan hipotesa kajian ini antara lain Sutoyo, (2016); Zulkifli, (2016) dan Fernando Reinhard Tjiabrata, (2017) yang menyatakan bahwa beban kerja mempengaruhi kinerja. Berdasarkan landasan teori pada bagian tinjauan pustaka di atas dan hasil-hasil kajian terdahulu maka hipotesa yang diajukan untuk selanjutnya diuji kembali dalam kajian ini sebagai berikut;

$\mathrm{H}_{1} \quad$; Beban kerja berpengaruh positif terhadap kinerja pegawai Dinas Catatan Sipil Kabupaten Buru.

Hasil penelitian yang tentang pengaruh lingkungan kerja terhadap kinerja pegawai pernah disampaikan Sutoyo, (2016); Fikratunil Khasifah, (2016); Zulkifli, (2016) dan Fernando Reinhard Tjiabrata, (2017) yang melalui hasil kajiannya mengatakan bahwa lingkungan kerja memiliki pengaruh yang signifikan terhadap kinerja pegawai. Berdasarkan landasan teori pada bagian tinjauan pustaka di atas dan hasil-hasil kajian terdahulu maka hipotesa yang diajukan untuk selanjutnya diuji kembali dalam kajian ini adalah;

$\mathrm{H}_{2}$; Lingkungan kerja berpengaruh positif terhadap kinerja pegawai Dinas Catatan Sipil Kabupaten Buru. 


\section{Metode Penelitian}

Penelitian ini digolongkan sebagai penelitian penjelasan (eksplanatory) karena berupaya untuk menjelaskan pengaruh beban kerja dan lingkungan kerja terhadap kinerja. Pendekatan dalam penelitian ini termasuk dalam penelitian kuantitatif. Model penelitiannya adalah model survei dengan menggunakan instrumen kuesioner. Populasi dalam kajian ini adalah seluruh pegawai Dinas Catatan Sipil Kabupaten Buru. Penarikan sampel menggunakan teknik sensus yakni seluruh populasi dijadikan sampel penelitian. Distribusi kuesioner dilakukan kepada seluruh sampel dan mendapatkan 39 responden sebagai sampel. Analisis data penelitian dilakukan dengan terlebih dulu menguji instrument penelitian dilanjutkan dengan uji asumsi klasik dan diakhiri dengan analisis regresi linier berganda.

\section{Hasil dan Pembahasan}

\section{Analisis Deskriptif}

Kecenderungan jawaban responden terhadap jawaban masing-masing variabel didasarkan pada nilai rata-rata skor jawaban yang selanjutnya dikatagorikan pada rentang skor berikut ini;

- Skor Minimum = 1

- Skor Maksimum = 5

- Lebar Skala $\quad=\frac{5-1}{5}=0.8$

Dengan demikian maka katagori skala ditentukan sebagai berikut;

$1.00-1.80=$ Sangat Tidak Setuju

$1.81-2.60=$ Tidak Setuju

$2.61-3.30=$ Netral

$3.31-4.20=$ Setuju

$4.21-5.00=$ Sangat Setuju

Distribusi dari masing-masing kategori tanggapan responden dengan menggunakan teknik pengukuran angka indeks rata-rata seperti yang disajikan dalam tabel berikut ini; 


\section{Distribusi Frekuensi Jawaban Responden}

\begin{tabular}{|c|c|c|c|c|c|c|c|c|}
\hline \multirow{3}{*}{ No. } & \multirow{3}{*}{ Item } & \multicolumn{5}{|c|}{ Skor } & \multirow{3}{*}{ Jmh } & \multirow{3}{*}{ Rata-Rata } \\
\hline & & 5 & 4 & 3 & 2 & 1 & & \\
\hline & & SS & $\mathrm{S}$ & $\mathbf{N}$ & TS & STS & & \\
\hline 1. & $\mathrm{X} 1.1$ & 12 & 22 & 2 & 3 & - & 39 & 4.10 \\
\hline 2. & $\mathrm{X} 1.2$ & 11 & 24 & 3 & 1 & - & 39 & 4.15 \\
\hline 3. & $\mathrm{X} 1.3$ & 12 & 19 & 6 & 2 & - & 39 & 4.05 \\
\hline 4. & $\mathrm{X} 1.4$ & 10 & 20 & 8 & 1 & - & 39 & 4.00 \\
\hline 5. & $\mathrm{X} 1.5$ & 8 & 21 & 9 & 1 & - & 39 & 3.92 \\
\hline \multicolumn{8}{|c|}{ Rata-Rata Beban Kerja $\left(X_{1}\right)$ : } & 4.04 \\
\hline 1. & $\mathrm{X} 2.1$ & 8 & 24 & 7 & - & - & 39 & 4.02 \\
\hline 2. & $\mathrm{X} 2.2$ & 9 & 21 & 8 & 1 & - & 39 & 3.97 \\
\hline 3. & $\mathrm{X} 2.3$ & 9 & 19 & 9 & 2 & - & 39 & 3.89 \\
\hline 4. & $\mathrm{X} 2.4$ & 11 & 22 & 4 & 2 & - & 39 & 4.07 \\
\hline 5. & $\mathrm{X} 2.5$ & 13 & 20 & 6 & - & - & 39 & 4.17 \\
\hline 6. & $\mathrm{X} 2.6$ & 8 & 21 & 9 & 1 & - & 39 & 3.92 \\
\hline 7. & $\mathrm{X} 2.7$ & 12 & 21 & 6 & - & - & 39 & 4.15 \\
\hline \multicolumn{8}{|c|}{ Rata-Rata Lingkungan Kerja $\left(\mathrm{X}_{2}\right)$ : } & 4.02 \\
\hline 1. & Y.1 & 7 & 23 & 9 & - & - & 39 & 3.94 \\
\hline 2. & Y.2 & 6 & 24 & 9 & - & - & 39 & 3.92 \\
\hline 3. & Y.3 & 7 & 21 & 9 & 2 & - & 39 & 3.84 \\
\hline 4. & Y4 & 6 & 20 & 12 & 1 & - & 39 & 3.79 \\
\hline 5. & Y.5 & 6 & 19 & 13 & 1 & - & 39 & 3.76 \\
\hline 6. & Y.6 & 5 & 22 & 12 & - & - & 39 & 3.82 \\
\hline \multicolumn{8}{|c|}{ Rata-Rata Kinerja $(\mathrm{Y})$ : } & 3.84 \\
\hline \multicolumn{7}{|c|}{ Total Rata-Rata Seluruh Variabel : } & \multicolumn{2}{|r|}{3.97} \\
\hline
\end{tabular}

Berdasarkan data pada di atas terlihat bahwa beban kerja memiliki besarnya nilai rata-rata sebesar 4.04 yang berarti bahwa responden setuju variabel ini. Hasil analisa di atas juga menunjukan bahwa item yang paling baik dalam menjelaskan beban kerja adalah item $\mathrm{X}_{1.2}$ yang menyatakan bahwa "Beban pekerjaan yang harus diselesaikan di kantor setiap hari tergolong besar" dengan rata-rata tertinggi yakni 4.15. Variabel kedua yakni variabel lingkungan kerja memiliki skor rata-rata sebesar 4.02 yang artinya bahwa responden setuju dengan pernyataan tentang variabel ini. Hasil analisa di atas juga menunjukan bahwa item yang paling baik dalam menjelaskan beban kerja adalah item $\mathrm{X}_{1.2}$ yang menyatakan bahwa "Keamanan kerja merupakan hal yang penting bagi karyawan" dengan rata-rata tertinggi yakni 4.17. Variabel terakhir yakni kinerja memiliki nilai rata-rata sebesar 3.84 yang berarti responden juga setuju dengan seluruh pernyataan tentang variabel ini. Hasil analisa di atas juga menunjukan bahwa item yang paling baik dalam menjelaskan beban kerja adalah item 
$\mathrm{X}_{1.2}$ yang menyatakan bahwa "Berusaha untuk tidak melakukan kesalahan dalam menyelesaikan tugas" dengan rata-rata tertinggi yakni 3.94.

\section{Uji Insrumen Penelitian}

Pengujian validitas dalam penelitian ini menggunakan pengujian construct validity yang dilakukan dengan teknik korelasi antar skor butir pertanyaan dalam suatu variabel yang diamati dengan skor totalnya, dengan menggunakan rumus korelasi product moment dengan level signifikansi 5\% dari nilai kritisnya dan nilai korelasi (Agusty, 2006). Sedangkan pengujian reliabilitas menggunakan pendekatan cronbach alpha pada masing-masing indikator variabel. Pengujian reliabilitas dilakukan dengan cara menghitung cronbach's alpha dalam masing-masing instrumen dalam satu variabel. Satu instrumen dikatakan reliabel jika memiliki cronbach's alpha lebih dari 0.6 (Agusty, 2006). Hasil pengujian masing-masing variabel terlihat pada tabel dibawah ini.

\section{Uji Validitas \& Reliabilitas}

\begin{tabular}{|c|c|c|c|c|}
\hline Variabel & $\begin{array}{l}\text { Korelasi } \\
\text { ( r ) }\end{array}$ & Ket & $\begin{array}{c}\text { Koefisien } \\
\text { Cronbach } \\
\text { Alpha }\end{array}$ & Ket \\
\hline $\mathrm{X} 1.1$ & 0.828 & Valid & \multirow{7}{*}{0.897} & \multirow{7}{*}{ Reliabel } \\
\hline $\mathrm{X} 1.2$ & 0.766 & Valid & & \\
\hline $\mathrm{X} 1.3$ & 0.859 & Valid & & \\
\hline $\mathrm{X} 1.4$ & 0.795 & Valid & & \\
\hline $\mathrm{X} 1.5$ & 0.766 & Valid & & \\
\hline $\mathrm{X} 1.6$ & 0.765 & Valid & & \\
\hline $\mathrm{X} 1.7$ & 0.734 & Valid & & \\
\hline $\mathrm{X} 2.1$ & 0.838 & Valid & \multirow{5}{*}{0.896} & \multirow{5}{*}{ Reliabel } \\
\hline$X 2.2$ & 0.838 & Valid & & \\
\hline $\mathrm{X} 2.3$ & 0.888 & Valid & & \\
\hline$\times 2.4$ & 0.774 & Valid & & \\
\hline$\times 2.5$ & 0.871 & Valid & & \\
\hline Y.1 & 0.841 & Valid & \multirow{6}{*}{0.949} & \multirow{6}{*}{ Reliabel } \\
\hline Y.2 & 0.874 & Valid & & \\
\hline Y.3 & 0.901 & Valid & & \\
\hline Y4 & 0.875 & Valid & & \\
\hline Y.5 & 0.930 & Valid & & \\
\hline Y.6 & 0.950 & Valid & & \\
\hline
\end{tabular}

Hasil uji validitas dan realibilitas instrumen di atas menunjukan hasil uji signifikan korelasi (r) lebih besar dari 0.3 dan memiliki nilai koefisien cronbach's alpha di atas 0.6 
sehingga variabel pada tiap item pertanyaan dikatakan valid dan reliabel untuk dapat digunakan dalam pengolahan data selanjutnya

\section{Uji Asumsi Klasik}

Pengujian asumsi klasik dalam kajian ini dumulai dengan uji normalitas data dengan menggunakan grafik normal probability plot. Grafik normal probability plot hasil analisis data menunjukkan bahwa titik-titik data menyebar disekitar garis diagonal serta penyebarannya mengikuti arah garis diagonal, dengan demikian sebaran data dapat dikatakan berdistribusi normal. Pengujian selanjutnya adalah uji heterokedastisitas. Priyatno, (2012) menyatakan bahwa model regresi yang baik seharusnya tidak terjadi heteroskedastisitas. Pengujian heteroskedastisitas dalam kajian ini adalah dengan melihat penyebaran titik-titik pada grafik scatterplot. Hasil analisis menunjukan bahwa titik-titik pada grafik scatterplot menyebar secara acak serta tersebar baik di atas maupun dibawah angka 0 pada sumbu Y. Hal ini menunjukan kaidah heteroskedastisitas dalam model penelitian ini terpenuhi. Pengujian asumsi kalsik yang terakhir adalah uji multikolinieritas yang dinilai berdasarkan nilai Variance Inflation Faktor (VIF) dan Tolerance. Hasil analisis menunjukan bahwa nilai Variance Inflation Faktor(VIF) melebihi 0.10 dan nilai Tolerance dibawah 1 yang berarti tidak terjadi multikolinearitas antar variabel independen dalam penelitian ini.

\section{Analisis Regresi Linier Berganda}

Hasil pengolahan data dengan menggunakan analisis regresi linear berganda, dilakukan untuk menguji pengaruh dari beban kerja $\left(X_{1}\right)$ dan lingkungan kerja $\left(X_{2}\right)$ terhadap kinerja pegawai (Y) pada Dinas Catatan Sipil di Kabupaten Buru.

\section{Hasil Analisis Regresi Linier Berganda}

\begin{tabular}{|c|c|c|c|c||}
\hline Variabel & $\begin{array}{c}\text { Unstandardized } \\
\text { Coefficients } \\
(\mathbf{B})\end{array}$ & t hitung & Sig. & Ket. \\
\hline Beban Kerja $\left(\mathrm{X}_{2}\right)$ & 0.345 & 2.138 & .039 & Signifikan \\
\hline Lingkungan Kerja $\left(\mathrm{X}_{1}\right)$ & 0.592 & 4.547 & .000 & Signifikan \\
\hline R Ajusted Square & 0.797 & & \\
\hline t hitung & 1.688 \\
\hline
\end{tabular}

Berdasarkan hasil analisis regresi linier berganda di atas, terlihat bahwa hasil pengujian hipótesis pertama mengungkapkan bahwa beban kerja yang terwakili melalui 5

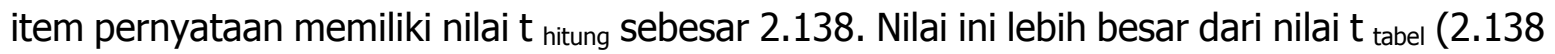


$>1.688$ ) dengan nilai koefisien sebesar 0.345 (positif) dengan nilai signifikansinya sebesar 0.039 yang adalah lebih kecil dibandingkan 0.05 (0.039 < 0.05). Artinya bahwa, terima $\mathrm{Ha}$ dan tolak $\mathrm{HO}$ atau hipotesis kedua diterima atau beban kerja berpengaruh positif dan signifikan terhadap kinerja pegawai Dinas Catatan Sipil di Kabupaten Buru. Hasil pengujian hipótesis kedua mengungkapkan bahwa lingkungan kerja memiliki nilai $t$ hitung sebesar 4.547. Nilai ini lebih besar dari nilai $t_{\text {tabel }}(4.547>1.688)$ dengan nilai koefisien yang positif sebesar 0.592 yang artinya bahwa, terima Ha dan tolak HO atau hipotesis diterima atau lingkungan kerja berpengaruh positif dan signifikan terhadap kinerja pegawai Dinas Catatan Sipil di Kabupaten Buru.

Secara singkat dapat dijelaskan bahwa beban kerja dan lingkungan kerja berpengaruh positif signifikan terhadap kinerja. Hal ini dapat dilihat dari tingkat signifikansi beban kerja dan lingkungan kerja yang di bawah 0,005 dengan pengaruh yang paling dominan berasalal dari variabel lingkungan kerja. Kinerja dapat dijelaskan oleh beban kerja dan lingkungan kerja sebesar 79.7 \%, yang ditunjukkan dari R Adjusted Square. Hal ini juga berarti bahwa kinerja dapat dijelaskan sebesar $20.3 \%$ oleh variabel lain di luar model.

\section{Pengaruh Beban Kerja dan Lingkungan Kerja Terhadap Kinerja}

Temuan penelitian ini adalah beban kerja berpengaruh terhadap kinerja pegawai di Dinas Catatan Sipil Kabupatern Buru. Hal tersebut berarti semakin tinggi beban kerja, maka semakin baik kinerja pegawainya. Walaupun beban kerja di kantor yang dikerjakan setiap hari tergolong besar, namun kinerja pegawai tetap prima. Hal ini dibuktikan dengan komitmen untuk tetap menyelesaikan beban kerja yang harus diselesaikan di Dinas Catatan Sipil. Temuan ini juga secara tidak langsung menunjukan bahwa semakin banyak beban kerja yang mampu diselesaikan maka kinerja pegawai akan semakin baik. Hasil penelitian ini mendukung hasil kajian sebelumnya oleh; Sutoyo, (2016); Zulkifli, (2016) dan Fernando Reinhard Tjiabrata, (2017) yang juga mengakui bahwa secara parsial terdapat pengaruh yang signifikan antara variabel beban kerja terhadap kinerja karyawan.

Berdasarkan hasil análisis khususnya bila dilihat dari distribusi frekuensi jawaban responden, maka terlihat bahwa item beban kerja penyumbang pengaruh paling dominan terhadap kinerja pegawai Dinas Catatan Sipil di Kabupaten Buru adalah item; $\mathrm{X}_{1.2}$ yang menyatakan bahwa "Beban pekerjaan yang harus diselesaikan di kantor setiap hari tergolong besar" dengan rata-rata tertinggi yakni 4.15. Temuan ini membuktikan bahwa 
persepsi pegawai beban kerja lebih didasarkan pada seberapa besar/banyak beban kerja yang harus diselesaikan di Dinas Catatan Sipil. Temuan ini juga secara tidak langsung menunjukan bahwa semakin banyak beban kerja yang mampu diselesaikan maka kinerja pegawai akan semakin baik. Hasil penelitian ini mendukung hasil kajian sebelumnya oleh; Sutoyo, (2016); Zulkifli, (2016) dan Fernando Reinhard Tjiabrata, (2017) yang juga mengakui bahwa secara parsial terdapat pengaruh yang signifikan antara variabel beban kerja terhadap kinerja karyawan

Berpengaruhnya lingkungan kerja yang terwakili melalui 7 item pernyataan, dapat dijelaskan melalui hasil analisis deskriptif yakni distrinusi jawaban responden. Hasil analisa tersebut menjunjukan bahwa sumbangan pengaruh terbesar kemampuan berasal dari item $\mathrm{X}_{1.2}$ yang menyatakan bahwa " Keamanan kerja merupakan hal yang penting bagi karyawan" dengan rata-rata tertinggi yakni 4.17. Hasil ini berarti bahwa persepsi lingkungan kerja akan semakin baik jika keamanan di tempat kerja juga semakin baik. Temuan ini juga dapat memberi gambaran bahwa kinerja pegawai Dinas Catatan Sipil akan semakin baik jika faktor keamanan di lingkungan kerja adalah baik. Hasil kajian ini mendukung hasil kajian sebelumnya oleh; Sutoyo, (2016); Fikratunil Khasifah, (2016); Zulkifli, (2016) dan Fernando Reinhard Tjiabrata, (2017) yang juga mengakui bahwa lingkungan kerja berpengaruh positif dan signifikan terhadap kinerja pegawai/karyawan.

\section{Penutup}

\section{Simpulan}

Berdasarkan pembahasan hasil penelitian maka kesimpulan yang dapat disampaikan melalui kajian ini adalah sebagai berikut;

1. Beban kerja terbukti berpengaruh positif dan signifikan terhadap kinerja pegawai Dinas Catatan Sipil Kabupaten Buru atau dapat dikatakan bahwa dorongan peningkatan beban kerja akan meningkatkan kinerja pegawai Dinas Catatan Sipil di Kabupaten Buru.

2. Lingkungan kerja terbukti berpengaruh secara positif dan signifikan terhadap kinerja pegawai Dinas Catatan Sipil Kabupaten Buru atau dapat dikatakan bahwa dorongan peningkatan lingkungan kerja akan meningkatkan kinerja pegawai Dinas Catatan Sipil di Kabupaten Buru. 
3. Hasil analisis membuktikan bahwa variabel yang memberikan pengaruh terbesar kepada kinerja pegawai Dinas Catatan Sipil di Kabupaten Buru adalah variabel lingkungan kerja.

\section{Rekomendasi}

Hasil penelitian menunjukkan bahwa beban kerja yang tinggi tidak membuat pegawai memiliki kinerja yang turun. Oleh karena itu manajemen Dinas Catatan Sipil Kabupaten Buru perlu memberikan apresiasi kepada pegawai dalam bentuk piagam penghargaan atau penghargaan yang sesuai dengan alur karier ASN seperti promosi. Demikian pula lingkungan kerja yang baik berpengaruh terhadap kinerja yang baik dari pegawai, sehingga perlu dipelihara kondusifitas lingkungan dengan cara menyiapkan peralatan untuk manjamin tingkat keamanan di tempat kerja.

\section{Daftar Pustaka}

Agripa Fernando Tarigan. (2011). Analisis Faktor - Faktor yang Mempengaruhi Kinerja Pegawai Dalam Organisasi Sektor Publik (Studi pada Kantor Pelayanan Pajak Pratama Semarang Tengah Satu). Universitas Diponegoro.

Agusty, F. (2006). Metode Penelitian Manajemen; Pedoman Penelitian Untuk Penulisan Skripsi, Tesis Dan Disertasi IImu Manajemen (2nd ed.). Semarang: Badan Penerbit Universitas Diponegoro.

Artha Tri Hastutiningsih. (2018). Pengaruh Beban Kerja dan Lingkungan Kerja Terhadap Kinerja Karyawan Dimediasi Stres Kerja (Studi Pada PT. MSV Pictures Yogyakarta) (Universitas Islam Indonesia Yogyakarta). https://doi.org/10.1017/CBO9781107415324.004

Aslian, M. Y. (2019). Dampak Persepsi Beban Kerja dan Lingkungan Kerja Terhadap Kinerja Karyawan Divisi SDM dan Umum PT. Swabina Gatra. Jurnal IImu Manajemen, ス3), 680-687.

Bernardin, H. J., \& Russel A. E. J. (1988). Human Resources Management: An Experimental Approach (2nd ed.). New York: Irwin McGraw-Hill Inc.

David Chan \& Neal Schmitt. (2002). Situational Judgment and Job Performance. Human Performance, 15(2). https://doi.org/10.1207/S15327043HUP1503_01

Eduard Yohannis Tamaela. (2011). Konsekuensi Konflik Peran, Kelebihan Beban Kerja dan Motivasi Intrinsik Terhadap Burnout Dosen yang Merangkap Jabatan Struktural. Aset, 
13(2), 111-122. Retrieved from

https://widyamanggala.ac.id/journal/index.php/jurnalaset/article/view/78/52

Eduard Yohannis Tamaela \& Surijadi Herman. (2018). The Burnout Antecedent Model

Extension and its Consequences to the Lecturer's Job Satisfaction Level in Private Colleges, Ambon. Scientific Research Journal, 6(3), 36-60. Retrieved from http://www.scirj.org/mar-2018-paper.php?rp=P0318513

Fernando Reinhard Tjiabrata, B. L. dan L. O. H. D. (2017). Pengaruh Beban Kerja dan Lingkungan Kerja Terhadap Kinerja Karyawan PT. Sabar Ganda Manado. Emba, 5(2), 1570-1580.

Fikratunil Khasifah, R. N. (2016). Pengaruh Disiplin Kerja, Beban Kerja dan Lingkungan Kerja Terhadap Kinerja Pegawai (Studi Pada Balai Besar Wilayah Sungai Pemali Juana). Diponegoro Journal of Management, 5(1), 1-7.

Kesehatan.kontan.co.id. (2019, April 22). beban-kerja-berlebihan-mengancam-nyawa? Kesehatan.Kontan.Co.Id. Retrieved from https://kesehatan.kontan.co.id/news/bebankerja-berlebihan-mengancam-nyawa?page=all

Komaruddin Sastradipoera. (1996). Pengantar Manajemen Perusahaan. Jakarta: Rajawali Pers.

Moekijat. (1999). Kamus Manajemen. Bandung: Mandar Maju.

Pratama, Ilham, H. tribunnews. com/nasional/2019/10/29/banyaknya-petugas-kppsmeninggal-saat-pemil.-2019-karena-beban-kerja., Pratama, P. I. R., \& Editor: (2019). Banyaknya Petugas KPPS Meninggal Saat Pemilu 2019 Karena Beban Kerja. $\begin{array}{lll}\text { Tribunnews.Com. } & \text { Retrieved from }\end{array}$ https://www.tribunnews.com/nasional/2019/10/29/banyaknya-petugas-kppsmeninggal-saat-pemilu-2019-karena-beban-kerja

Priyatno, D. (2012). Belajar Cepat Olah Data Statistik Dengan SPSS. Yogyakarta: Andi.

Riny Chandra dan Dody Adriansyah. (2015). Pengaruh Beban Kerja Dan Stres Kerja Terhadap Kinerja Karyawan Pada Pt. Mega Auto Central Finance Cabang Di Langsa. Jurnal IImiah Magister Managemen Unikom, 5(1), 670-678. https://doi.org/10.37751/parameter.v4i2.37

Sedarmayanti. (2009). Sumber Daya Manusia dan Produktivitas Kerja. Bandung: Mandar Maju. 
Soegoto, D. R. \& H. (2018). Pengaruh Beban Kerja, Kompetensi, dan Lingkungan Kerja Terhadap Stres Kerja serta Implikasinya Terhadap Kinerja Pegawai PT BCA Finance. Jurnal IImiah Magister Managemen Unikom, 1-15.

Surijadi, H., \& Idris, Y. (2020). Dampak Lingkungan Kerja Fisik dan Lingkungan Kerja Non Fisik Terhadap Kepuasan Kerja Karyawan. Public Policy (Jurnal Aplikasi Kebijakan Publik \& Bisnis), 1(1), 14-32. Retrieved from https://stia-saidperintah.ejournal.id/ppj/article/view/2

Sutoyo. (2016). Pengaruh Beban Kerja, Lingkungan Kerja dan Motivasi Terhadap Kinerja Pegawai pada Dinas Bina Marga Propinsi Sulawesi Tengah. Jurnal Katalogis, 4(3), 187195. Retrieved from https://media.neliti.com/media/publications/157073-IDpengaruh-beban-kerja-lingkungan-kerja-da.pdf

Tamaela, E. Y., Hetharie, J. A., \& Huwae, V. E. (2018). Extension and Consequence of Burnout Antecedent Model to Job Satisfaction of College Lecturers who Concurrent Structural Position at Private-Owned University in Islands of Ambon, Indonesia. Russian Journal of Agricultural and Socio-Economic Sciences, 775), 74-85. https://doi.org/10.18551/rjoas.2018-05.10

Zulkifli. (2016). Pengaruh Beban Kerja, Lingkungan Kerja dan Kompensasi Terhadap Kinerja Dosen Universitas Jabal Ghafur. Journal of Economic Management \& Business, 1入1), $105-116$. 